\title{
Efek Peluruhan Kalsium Batu Ginjal Fraksi Etil Asetat Daun Nona Makan Sirih (Clerodendron thomsonae Balf.f.) Secara In Vitro
}

\author{
Neta Novalia*, Adam M. Ramadhan, Arsyik Ibrahim \\ Laboratorium Penelitian dan Pengembangan FARMAKA TROPIS \\ Fakultas Farmasi Universitas Mulawarman, Samarinda, Kalimantan Timur \\ *Email: Netanovalia@gmail.com
}

\begin{abstract}
ABSTRAK
Batu ginjal merupakan masalah kesehatan yang menempati urutan ketiga dibidang urologi setelah infeksi saluran kemih dan pembesaran prostat. Salah satu pengobatan tradisional untuk penderita batu ginjal adalah dengan daun nona makan sirih. Penelitian ini bertujuan untuk mengetahui rendemen, efek dan konsentrasi terbaik dari fraksi etil asetat daun nona makan sirih terhadap kelarutan kalsium batu ginjal. Batu ginjal sebanyak 100 mg direndam dalam fraksi etil asetat dimana fraksi etil asetat dibuat 5 variasi konsentrasi yaitu $2,5 \% ; 5 \% ; 7,5 \% ; 10 \% ; 12,5 \%$ kemudian diinkubasi selama 6 jam $\left(37^{\circ} \mathrm{C}\right)$. Filtrat diukur kadar kalsium dengan spektrofotometer $U V$-Vis pada $\lambda 495 \mathrm{~nm}$. Rendemen fraksi etil asetat diperoleh sebesar 1,118\%. Fraksi etil asetat memiliki aktivitas terhadap kelarutan kalsium batu ginjal dan hasil pengukuran rata-rata kadar kalsium terlarut masing-masing sebesar 136,516; 149,767; 171,175; 194,933; dan 158,106 $\mu \mathrm{g} / \mathrm{mL}$ dan konsentrasi terbaik yaitu $10 \%$ dengan kadar kalsium terlarut sebesar 194,933 $\mu \mathrm{g} / \mathrm{mL}$.
\end{abstract}

Kata kunci: Daun nona makan sirih, Fraksi etil asetat, Kelarutan kalsium batu ginjal

\section{ABSTRACT}

Kidney stones is a health problem that ranks third in the field of urology after a urinary tract infection and prostate enlargement. One of the traditional treatment for patients with kidney stones is the nona makan sirih leaves. This research aims to determine yield, the effects and the best concentration of the ethyl acetate fraction of nona makan sirih leaves on the solubility of calcium kidney stones. Kidney stones are soaked in as much as $100 \mathrm{mg}$ of ethyl acetate fraction, which fraction of ethyl acetate was made five variations in the concentration of 2,5\%;5\%;7,5\%;10\%;12,5\% were then incubated for 6 hours $\left(37^{\circ} \mathrm{C}\right)$. The filtrate calcium levels measured by UV-Vis spectrophotometer at $\lambda 495$ $\mathrm{nm}$. The yield of ethyl acetate fraction obtained at 1.118\%. Ethyl acetate fraction had activity on the solubility of calcium kidney stones and the results averaged measured of dissolved calcium levels 136.516; 149.767; 171.175; 194.933; and 158.106 $\mu \mathrm{g} / \mathrm{mL}$ and the best concentration of $10 \%$ with levels of dissolved calcium $194.933 \mu \mathrm{g} / \mathrm{mL}$.

Keywords: Nona makan sirih leaves, Fraction of ethyl acetate, Solubility of calcium kidney stones

\section{PENDAHULUAN}

Penyakit batu ginjal adalah penyakit yang disebabkan oleh adanya sedimen urin dalam ginjal dan saluran kemih. Batu tersebut akan lebih cepat terbentuk apabila urin 
sangat pekat dan tidak minum cukup banyak air. Penyakit batu ginjal merupakan penyakit ketiga terbanyak di bidang urologi setelah infeksi saluran kemih dan pembesaran prostat(Purnomo, 2011).

Angka prevalensi penderita penyakit batu ginjal di Indonesia sebesar 51,9 per 10.000 penduduk dengan resiko penderita lebih banyak dialami pria daripada wanita dengan perbandingan 3:1. Umumnya penderita pada usia produktif (20-50 tahun), dan hanya sebagian kecil penyakit batu ginjal ini menyerang anak-anak (Soenanto,2005).

Batu kalsium merupakan jenis batu paling banyak dijumpai, yaitu kurang lebih 70$80 \%$ dari seluruh batu saluran kemih, baik yang berikatan dengan oksalat maupun dengan fosfat membentuk batu kalsium oksalat dan kalsium fosfat, sedangkan sisanya berasal dari batu asam urat, batu magnesium ammonium fosfat (struvit) dan batu sistin. Batu ginjal dapat dikeluarkan melalui tindakan endourologi, pembedahan, dan obat untuk mengurangi nyeri serta memperlancar aliran urin dengan pemberian diuretik (Purnomo, 2011).

Pengobatan yang popular adalah lithotripsy (pemecah batu) yang bukan merupakan tindakan operasi tetapi membutuhkan biaya mahal (4,5 juta rupiah per tindakan) dan tindakan biasanya dilakukan lebih dari satu kali (Nefro, 2004).

Salah satu tanaman yang digunakan masyarakat suku Dayak secara empiris untuk mengobati penyakit batu ginjal adalah daun nona makan sirih (Clerodendron thomsonae Balf.f.). Masyarakat suku Dayak menggunakan daun nona makan sirih untuk mengobati penyakit batu ginjal dengan cara daun nona makan sirih direbus dengan air dan diminum air rebusannya.

Menurut Djumidi (1997), daun nona makan sirih (Clerodendron thomsonae Balf.f.) mengandung senyawa saponin, polifenol, alkaloid dan flavonoid. Kalsium batu ginjal diduga dapat membentuk senyawa kompleks dengan gugus - $\mathrm{OH}$ dari flavonoid sehingga membentuk Ca-flavonoid. Senyawa kompleks ini diduga lebih mudah larut dalam air, sehingga air yang ada dalam urin akan membantu kelarutan batu ginjal (Nessa, 2013).

Penelitian ini bertujuan untuk mengetahui rendemen fraksi etil asetat daun nona makan sirih (Clerodendron thomsonae Balf.f.) hasil fraksinasi dengan etil asetat, mengetahui efek dari fraksi etil asetat daun nona makan sirih (Clerodendron thomsonae Balf.f.) dalam melarutkan kalsium batu ginjal secara in vitro, dan mengetahui konsentrasi terbaik dari fraksi etil asetat daun nona makan sirih (Clerodendron thomsonae Balf.f.) untuk melarutkan kalsium batu ginjal secara in vitro.

\section{METODE PENELITIAN}

Jenis penelitian ini adalah penelitian kuantitatif eksperimental. Variabel bebas meliputi variasi konsentrasi fraksi etil asetat daun nona makan sirih. Variabel terikat meliputi konsentrasi kalsium batu ginjal yang terlarut.

\section{Bahan}

Daun nona makan sirih, etil asetat, batu ginjal, pereaksi mureksid, $\mathrm{NaOH}$, aquades, kalsium klorida, amonium karbonat, asam sulfat, perak nitrat, barium klorida.

\section{Peralatan}

Corong pisah, inkubator, mortir dan stamper, spektrofotometer UV-Vis, timbangan analitik dan peralatan gelas. 


\section{Prosedur}

\section{Pembuatan Ekstrak Air dan Fraksi Etil Asetat Daun Nona Makan Sirih}

Daun segar nona makan sirih diekstraksi dengan metode infus menggunakan pelarut air. Kemudian difraksinasi dengan pelarut etil asetat hingga lapisan etil asetat jernih dan fraksi yang diperoleh dipekatkan hingga diperoleh ekstrak kental daun nona makan sirih dan dihitung rendemen.

\section{Analisis Kualitatif Kalsium Batu Ginjal}

Ditimbang $100 \mathrm{mg}$ batu ginjal kemudian dilarutkan dengan asam mineral dan ditetesi dengan larutan amonium karbonat. Jika positif mengandung kalsium maka akan terbentuk endapan putih kalsium karbonat yang larut dalam asam asetat. Selanjutnya larutan batu ginjal ditetesi asam sulfat encer, diperoleh hasil positif jika terbentuk endapan putih yang larut dalam air.

\section{Penentuan Panjang Gelombang Maksimum}

Larutan baku kalsium klorida 10 ppm diambil $1 \mathrm{~mL}$ dan dimasukkan pada labu ukur $25 \mathrm{~mL}$. Setelah itu, ditambahkan pereaksi mureksid sebanyak $1 \mathrm{~mL}$ dan $\mathrm{NaOH} 0,1 \mathrm{~N}$ sebanyak $2 \mathrm{~mL}$ kemudian ditambahkan aquades hingga $25 \mathrm{~mL}$ dan dihomogenkan. Selanjutnya, larutan dimasukkan ke dalam kuvet dan dibaca pada panjang gelombang 400$700 \mathrm{~nm}$.

\section{Pembuatan Kurva Baku Kalsium}

Larutan kalsium klorida standar 1000 ppm, dibuat seri konsentrasi dengan konsentrasi 2, 4, 6, 8 dan $10 \mathrm{ppm}$. Pengukuran absorbansi dilakukan dengan menggunakan spektrofotometer $U V$-Visible pada panjang gelombang $495 \mathrm{~nm}$.

\section{Pengujian Kelarutan Kalsium Batu Ginjal}

Fraksi etil asetat daun nona makan sirih dan kontrol positif (batugin sirup) dibuat konsentrasi 2,5\%, 5\%, 7,5\%, 10\% dan 12,5\% sebanyak $10 \mathrm{~mL}$. Batu ginjal yang telah ditimbang sebanyak $100 \mathrm{mg}$ direndam pada masing-masing larutan seri konsentrasi pada suhu $37^{\circ} \mathrm{C}$ selama 6 jam sambil digojog setiap 15 menit, kemudian dilakukan penyaringan dengan kertas saring. Filtrat yang diperoleh diambil sebanyak $1 \mathrm{~mL}$ kemudian ditambahkan dengan pereaksi Mureksid sebanyak $1 \mathrm{~mL}$ dan $\mathrm{NaOH}$ sebanyak $2 \mathrm{~mL}$. Selanjutnya ditambahkan aquades hingga $25 \mathrm{~mL}$ dan dihomogenkan. Setelah itu, diukur absorbansinya menggunakan spektrofotometer $U V$-Visible pada panjang gelombang maksimum, yaitu $495 \mathrm{~nm}$.

\section{HASIL DAN PEMBAHASAN}

\section{Analisis Kualitatif Kalsium Batu Ginjal}

Batu ginjal yang diperoleh diidentifikasi secara kualitatif dengan beberapa pereaksi spesifik. Pereaksi pertama adalah amonium karbonat menghasilkan reaksi positif mengandung kalsium berupa terbentuknya endapan putih kalsium karbonat $\left(\mathrm{CaCO}_{3}\right)$ yang larut dalam asam asetat. Pereaksi kedua adalah asam sulfat encer menghasilkan reaksi positif mengandung kalsium berupa terbentuknya endapan putih kalsium sulfat $\left(\mathrm{CaSO}_{4}\right)$ yang sedikit larut dalam air. Pereaksi ketiga adalah perak nitrat yang menghasilkan reaksi positif berupa terbentuknya endapan putih yang sangat sedikit larut dalam air yang menandakan adanya ion oksalat. Pereaksi keempat adalah barium klorida yang 
menghasilkan reaksi positif berupa terbentuknya endapan putih yang menandakan adanya ion fosfat.

Tabel 1. Data Jenis Batu Ginjal

\begin{tabular}{clcl}
\hline Sampel & \multicolumn{1}{c}{ Pereaksi Kimia } & Hasil $(+/-)$ & \multicolumn{1}{c}{ Keterangan } \\
\hline \multirow{3}{*}{ Batu } & Amonium karbonat & + & Endapan larut asam asetat \\
Ginjal & Asam sulfat encer & + & Endapan larut air \\
& Perak nitrat & + & Terdapat ion oksalat \\
& Barium klorida & + & Terdapat ion fosfat \\
\hline
\end{tabular}

Keterangan:

(+) : terbentuk endapan putih

$(-) \quad$ : tidak terbentuk endapan putih

\section{Rendemen}

Ekstraksi daun nona makan sirih dengan metode infus menggunakan pelarut air. Infus yang diperoleh kemudian difraksinasi. Fraksinasi dilakukan dengan metode cair-cair menggunakan pelarut etil asetat dan fraksi yang diperoleh kemudian diuapkan sehingga diperoleh rendemen fraksi etil asetat daun nona makan sirih sebesar 1,118\%.

Tabel 2. Data Rendemen Fraksi Daun Nona Makan Sirih

\begin{tabular}{cccc}
\hline No & \multicolumn{1}{c}{ Sampel } & $\begin{array}{c}\text { Berat Ekstrak } \\
\text { (gram) }\end{array}$ & $\begin{array}{c}\text { Rendemen Fraksi Terhadap Sampel } \\
\text { Segar }(\%)\end{array}$ \\
\hline 1. & Sampel segar & 200 & - \\
2. & Fraksi Etil Asetat & 2,237 & 1,118 \\
\hline
\end{tabular}

\section{Penentuan Kurva Baku}

Kurva baku kalsium dibuat dari baku kalsium klorida dengan konsentrasi 2; 4; 6; 8; dan $10 \mathrm{ppm}$. Pengukuran dilakukan dengan spektrofotometer $U V$-Visible pada panjang gelombang $495 \mathrm{~nm}$. Hasil penentuan kurva baku kalsium klorida berupa hubungan antara konsentrasi (x) dan absorbansi (y).

Hasil perhitungan dengan regresi linier diperoleh nilai a sebesar 0,272 , nilai $b$ sebesar 0,098 dan nilai $\mathrm{r}$ sebesar 0,996, sehingga diperoleh persamaan regresi linier $\mathrm{y}=$ $0,098 x+0,272$. Persamaan regresi linier ini digunakan untuk menghitung kadar kalsium yang terlarut dalam fraksi etil asetat daun nona makan sirih.

Kadar kalsium total digunakan untuk menghitung kadar kalsium terlarut dengan rumus: $\quad$ Kadar $C a_{\text {terlarut }}=$ Kadar $C a_{\text {total }}-$ Kadar Ca $a_{\text {blanko }}$

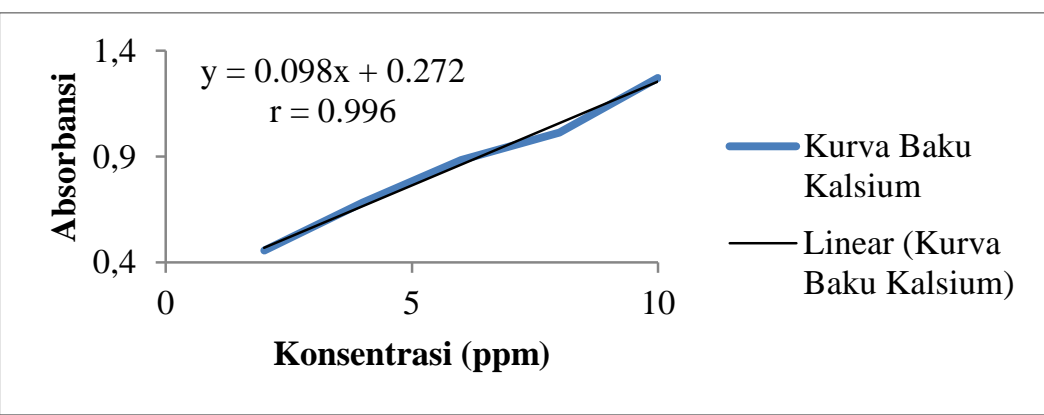

Gambar 1. Hubungan antara konsentrasi kalsium dan absorbansi 


\section{Pengukuran Kadar Kalsium Batu Ginjal}

Spektrofotometri $U V$-Vis adalah pengukuran panjang gelombang dan intensitas sinar ultraviolet dan cahaya tampak yang diabsorbsi oleh sampel. Sinar ultraviolet dan cahaya tampak memiliki energi yang cukup untuk mempromosikan elektron pada kulit terluar ke tingkat energi yang lebih tinggi. Sinar ultraviolet mempunyai panjang gelombang antara 200-400 nm, sementara sinar tampak mempunyai panjang gelombang 400-800 nm (Dachriyanus, 2004).

Prinsip dari spektrofotometri $U V$-Vis adalah mengukur jumlah cahaya yang diabsorbsi atau ditransmisikan oleh molekul-molekul di dalam larutan. Ketika panjang gelombang cahaya ditransmisikan melalui larutan, sebagian energi cahaya tersebut akan diserap (diabsorpsi). Besarnya kemampuan molekul-molekul zat terlarut untuk mengabsorbsi cahaya pada panjang gelombang tertentu dikenal dengan istilah absorbansi (A), yang setara dengan nilai konsentrasi larutan tersebut (Harmita, 2006).

Penetapan kadar kalsium dengan spektrofotometer $U V$-Vis didasarkan pada pembentukkan kompleks kalsium mureksid dalam suasana basa (Rahayu, 2011).

Pengukuran kadar kalsium dengan Spektrofotometer $U V$-Vis dilakukan pada panjang gelombang maksimal $495 \mathrm{~nm}$. Hasil pengukuran kadar kalsium batu ginjal yang terlarut pada fraksi etil asetat daun nona makan sirih dapat dilihat pada tabel 3. Sedangkan hasil pengukuran kadar kalsium batu ginjal yang terlarut dalam kontrol positif (batugin sirup) dapat dilihat pada tabel 4.

Tabel 3. Kadar Kalsium Batu Ginjal Terlarut dalam Fraksi Etil Asetat Daun Nona Makan Sirih

\begin{tabular}{ccccccc}
\hline \multirow{2}{*}{ Replikasi } & \multicolumn{6}{c}{ Konsentrasi $(\%)$} \\
\cline { 2 - 6 } & 0 & $2,5 \%$ & $5 \%$ & $7,5 \%$ & $10 \%$ & $12,5 \%$ \\
\hline & 0 & 136,425 & 149,425 & 169,300 & 194,500 & 156,825 \\
2 & 0 & 136,950 & 149,425 & 171,600 & 194,500 & 157,600 \\
3 & 0 & 136,175 & 150,450 & 172,625 & 195,800 & 159,625 \\
\hline$\Sigma$ & 0 & 409,550 & 449,300 & 513,525 & 584,800 & 474,050 \\
$\bar{x}$ & 0 & 136,516 & 149,767 & 171,175 & 194,933 & 158,016 \\
\hline
\end{tabular}

Tabel 4. Kadar Kalsium Batu Ginjal Terlarut dalam Batugin Sirup

\begin{tabular}{cllllll}
\hline & \multicolumn{6}{c}{ Kadar Kalsium Terlarut $(\mu \mathrm{g} / \mathrm{mL})$} \\
\cline { 2 - 6 } Replikasi & \multicolumn{6}{c}{ Konsentrasi $(\%)$} \\
\cline { 2 - 7 } & 0 & $2,5 \%$ & $5 \%$ & $7,5 \%$ & $10 \%$ & $12,5 \%$ \\
\hline 1 & 0 & 9,602 & 15,200 & 46,525 & 79,900 & 87,525 \\
2 & 0 & 6,800 & 15,950 & 46,525 & 80,900 & 87,025 \\
3 & 0 & 8,825 & 16,475 & 43,725 & 76,575 & 87,525 \\
\hline$\Sigma$ & 0 & 25,227 & 47,625 & 136,775 & 237,375 & 262,075 \\
$\bar{x}$ & 0 & 8,409 & 15,875 & 45,591 & 79,125 & 87,358 \\
\hline
\end{tabular}

Hasil pengukuran rata-rata kadar kalsium terlarut dalam fraksi etil asetat daun nona makan sirih pada konsentrasi 2,5\%; $5 \% ; 7,5 \% ; 10 \% ; 12,5 \%$ berturut-turut adalah 136,516; 149,$767 ; 171,175 ; 194,933$; dan $158,016 \mu \mathrm{g} / \mathrm{mL}$. Sedangkan kadar kalsium terlarut dalam batugin sirup pada konsentrasi $2,5 \% ; 5 \% ; 7,5 \% ; 10 \% ; 12,5 \%$ berturut-turut adalah 8,409 ; 15,$875 ; 45,591 ; 79,125$ dan $87,358 \mu \mathrm{g} / \mathrm{mL}$. 


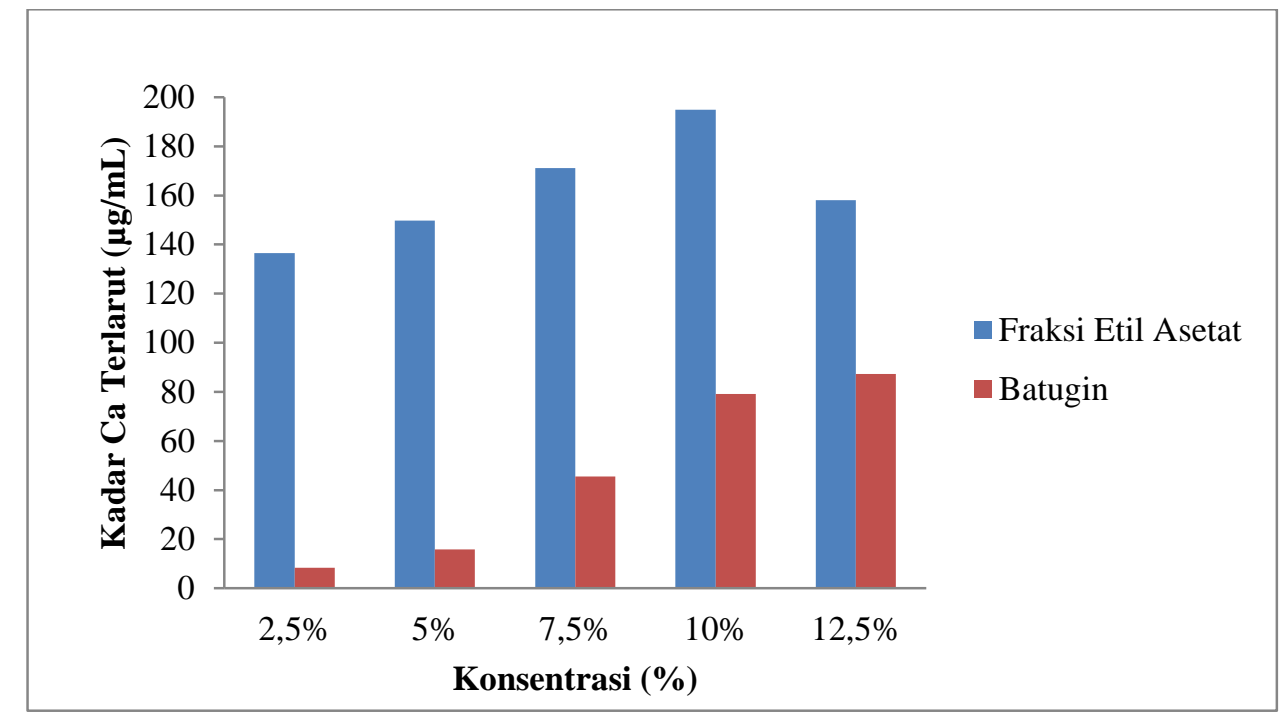

Gambar 2. Diagram Perbandingan Kadar Kalsium Terlarut dalam Fraksi Etil Asetat dan Batugin

Berdasarkan diagram pada gambar 2. dapat dilihat bahwa kelarutan kalsium batu ginjal dalam fraksi etil asetat daun nona makan sirih dan kontrol positif (batugin sirup) terus meningkat sesuai dengan peningkatan konsentrasi sampel hingga konsentrasi $10 \%$ untuk fraksi etil asetat dan 12,5\% untuk batugin sirup. Namun pada konsentrasi $12,5 \%$ kadar kalsium batu ginjal yang terlarut pada fraksi etil asetat menurun. Penurunan ini dapat terjadi karena larutan sampel yang sangat pekat sehingga kemampuan fraksi untuk melarutkan kalsium batu ginjal pada konsentrasi 12,5\% menjadi menurun sehingga diperoleh kadar kalsium yang lebih rendah dibandingkan dengan fraksi etil asetat konsentrasi $10 \%$.

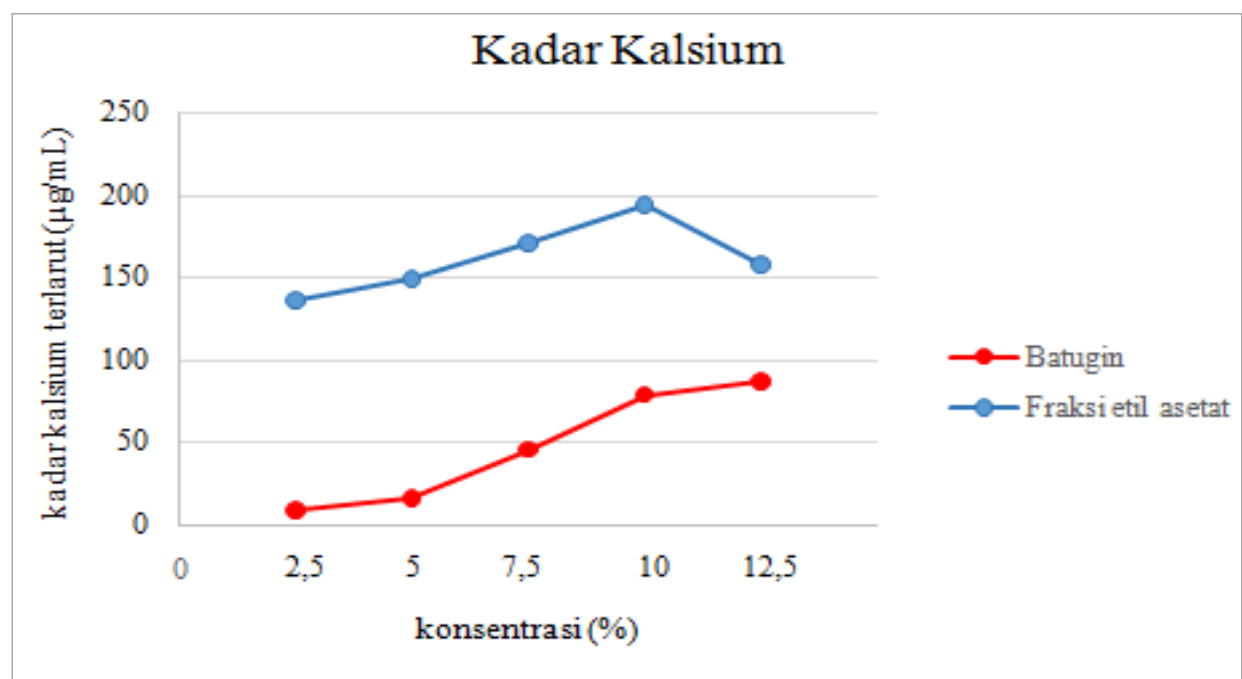

Gambar 3. Grafik Konsentrasi Terbaik Fraksi Etil Asetat Daun Nona Makan Sirih

Berdasarkan grafik pada gambar 3. dapat dilihat bahwa kelarutan kalsium batu ginjal dalam fraksi etil asetat daun nona makan sirih dan kontrol positif (batugin sirup) 
terus meningkat sesuai dengan peningkatan konsentrasi hingga konsentrasi $10 \%$ untuk fraksi etil asetat dan $12,5 \%$ untuk batugin sirup.

Hasil analisis Anava satu arah menunjukkan $F_{\text {hitung }}>F_{\text {tabel }}(P: 0,01)$ sehingga dapat diketahui adanya perbedaan yang sangat signifikan antara lima variasi konsentrasi. Hal ini menunjukkan bahwa variasi konsentrasi fraksi etil asetat daun nona makan sirih mempengaruhi kelarutan kalsium batu ginjal. Hal ini juga menunjukkan bahwa setiap variasi fraksi etil asetat daun nona makan sirih memiliki perbedaan yang nyata dalam melarutkan kalsium batu ginjal. Konsentrasi terbaik ditentukan dengan uji lanjutan BNJD (Beda Nyata Jujur Duncan) karena Koefisien Keseragaman (KK) yang diperoleh lebih dari $10 \%$.

Berdasarkan uji lanjutan BNJD, seluruh variasi konsentrasi menunjukkan perbedaan yang sangat signifikan dalam memberikan efek melarutkan kalsium batu ginjal. Sehingga dapat diketahui konsentrasi terbaik fraksi etil asetat daun nona makan sirih dalam melarutkan kalsium batu ginjal secara in vitro adalah $10 \%$.

Konsentrasi terbaik dari fraksi etil asetat daun nona makan sirih dalam melarutkan kalsium batu ginjal adalah $10 \%$. Hasil uji-t menunjukkan terdapat perbedaan yang signifikan $(\mathrm{p}>0,05)$ antara fraksi etil asetat daun nona makan sirih dengan batugin sirup dalam melarutkan kalsium batu ginjal secara in vitro.

Kalsium pada batu ginjal diduga dapat membentuk senyawa kompleks dengan dengan gugus $-\mathrm{OH}$ dari flavonoid sehingga membentuk Ca-flavonoid. Senyawa kompleks ini diduga lebih mudah larut dalam air, sehingga air yang ada dalam urin akan membantu kelarutan batu tersebut. Aktivitas diuretik dari flavonoid dapat membantu pengeluaran batu dari dalam ginjal yaitu dikeluarkan bersama dengan urin (Suharjo, 2009).

\section{KESIMPULAN}

1. Rendemen fraksi etil asetat daun nona makan sirih (Clerodendron thomsonae Balf.f.) sebesar $1,118 \%$.

2. Fraksi etil asetat daun nona makan sirih (Clerodendron thomsonae Balf.f.) memiliki efek dalam melarutkan kalsium batu ginjal secara in vitro.

3. Fraksi etil asetat daun nona makan sirih (Clerodendron thomsonae Balf.f.) dapat melarutkan kalsium batu ginjal secara in vitro dengan konsentrasi terbaik $10 \%$.

\section{DAFTAR PUSTAKA}

Dachriyanus. 2004. Analisis Struktur Senyawa Organik Secara Spektroskopi. Cetakan I. Padang: Andalas University Press.

Djumidi, H., Sutjipto, Sugeng S. 1997. Inventaris Tanaman Obat Indonesia (IV). Jakarta: Departemen Kesehatan Republik Indonesia.

Harmita, A.P.T. 2006. Analisa Fisikokimia. Jakarta: UI Press.

Nefro, K. dan Lumenta. 2004. Kenali Jenis Penyakit dan Cara Penyembuhan. Jakarta: PT Elex Media Komputindo.

Nessa, Helmi Arifin, Husni Muchtar. 2013. Efek Diuretik dan Daya Larut Batu Ginjal dari Ekstrak Etanol Rambut Jagung (Zea mays L.). Prosiding Seminar Nasional Perkembangan Terkini Sains Farmasi dan Klinik III.

Purnomo. 2011. Dasar-Dasar Urologi. Jakarta: Sagung Seto.

Rahayu, Sri Wiranti., Pri Iswati Utami., Anis Kurniawati. 2011. Validitas Penetapan Kadar Kalsium dalam Sediaan Tablet Multivitamin Secara Spektrofotometri UltravioletVisibel. Jurnal Pharmacy Vol.06 No.01. ISSN 1693-3591.

Soenanto, H. 2005. Musnahkan Penyakit dengan Tanaman Obat. Jakarta: Puspa Swara.

Suharjo, J.B. dan Cahyono, B. 2009. Batu Ginjal. Yogyakarta: Kanisius. 